\title{
Impact of literacy status on Participation of Tribal Women in Panchayati Raj - A case study of Nilgiri ITDA Block of Balasore district in Odisha.
}

\author{
Gadadhar Behera \\ Lecturer in Political ScienceBaba panchalingeswar Degree CollegeSantaragadia, Dist-Balasore, Odisha
}

\begin{abstract}
Education is such a powerful parameter, which is necessary for any value judgment, any political participation or any decision making. Odisha occupies a special position in the tribal map of India. It is regarded as homeland of the tribals. In this state the scheduled tribes comprise of 62 communities constitute 22.8 per cent of the total population of the state as per 2011 Census. These communities reside in almost all the districts of the state. Their concentration is very high above $50 \%$ in three individual district namely Koraput, Sundargarh and Mayurbhanj and some regions of six other districts such as Phulbani, Kalahandi, Ganjam, Kenojhar, Balasore and Sambalpur. In terms of tribal concentration, Odisha ranks third position next to Madhya Pradesh and Maharastra.
\end{abstract}

The general tribal population of Odisha is in poorer situation as compared to the general population. The tribal communities of Odisha are still far behind in almost all the standard parameters of development. They are not able to participate in the process of development, as they are not aware of the most programmes, policies made for their up-liftment. This is mainly due to the high incidence of illiteracy and very low level of education among the tribal people.

Despite the sincere and concentrated effort by the government for the overall development of scheduled tribe, they are still far behind in almost all the standard parameters of development. They are not able to participate in the process of development, as they are not aware of the most programmes and policies made for their up-liftment. This is mainly due to the high incidence of illiteracy and very low level of education $(63.1 \%)$ among the tribal people. Hence the educational status of the scheduled tribes needs to be assessed. The rationale for recognizing literacy as a right is the set of benefits it confers on individuals, families, communities and nations. Indeed, it is widely reckoned that, in modern societies, 'literacy skills are fundamental to informed decision-making, personal empowerment, active and passive participation in local and global social community. The human benefits from literature are related to factors such as the improved self-esteem, empowerment, creativity and critical reflection that participation in adult literacy programmes and the practice of literacy may produce. Human benefits are intrinsically valuable and may also be instrumental in realizing other benefits of literacy: improved health, increased political participation and so on.

Literacy may empower learners - especially women - to take individual and collective action in various contexts, such as household, workplace and community, in two related ways. First, literacy programmes themselves may be designed and conducted so as to make participants 'into authors of their own learning, developers of their own knowledge and partners in dialogue about limit situations in their lives. The relationship between education and political participation is well established. Educated people are to some extent more likely to vote and voice more tolerant attitudes and democratic values Participation in adult literacy programmes is also correlated with increased participation in trade unions, community action and national political life, especially when empowerment is at the core of programme design.

There is considerable divergence, differentiation among various tribal groups in terms of rites, rituals and functions. Since independence, there has been growing realization that development would never become self-sustaining unless it is accompanied by corresponding changes in the attitudes, values, knowledge and skills of the people in general and scheduled tribes in particular. The only way of accomplishing this change is through education. In this background, the analysis of education of tribals assumes great significance. Hence this is an attempt to study the impact of education on tribal women on their participation in PRI system.

\section{Sampling Design:}

The study is based on the field level data collected from a sample, selected from scheduled tribe households of Nilgiri ITDA Block in Balasore district of Odisha. A multistage sampling technique has been used to select households for the purpose of questionnaire. 


\section{Selection of Block:}

Nilgiri Block of Balasore district, Odisha is purposefully selected as the area of the present study, as it has the largest concentration of tribal population as well as the Block has been declared as the most backward and underdeveloped block in the country ( named as Gandhi Block) and special programmes are being undertaken to improve its socio-economic status.

\section{Selection of Gram Panchayats:}

Selection of Gram Panchayats become the second stage sampling. There are twenty three gram Panchayats operating in the block. Accordingly, three gram Panchayat are selected for the study purpose. As such the Gram Panchayats are namely Bhaunriabad, Matiali, and Mahisapata are selected at random.

\section{Selection of Village and Households:}

After selection of gram Panchayats, three villages are selected at random, where three dominant tribal communities are living. The total number of scheduled tribe households in the selected villages are then listed and classified according to community. From among the different tribal communities, three dominant communities are chosen for the purpose of study. Accordingly, the Kolhas, the Bathudis and the Bhumijas being three dominant community are selected and from the total sample households have been surveyed.

Thus, a total of 112 households from Kolha Community, 93 households from Bathudi community and 85 households from Bhumija community ( a total of 290 tribal households) are selected for the purpose of study.

\section{Collection of Data:}

The data relevant for the study have been collected both at the primary and secondary level. A household schedule specially designed for the purpose is used for collecting data at the field level. Through household schedule, required information of the sample households are obtained. Direct personal interview method has been followed to elicit information needed for the study. Besides, data are also collected from various secondary sources like Census 2001, 2011, official records of ITDA Project office, Nilgiri, ICDS Nilgiri, BDO, Nilgiri Odisha, Planning and Coordination Department, SC.ST Development Department, Govt. of Odisha, Director of Economics and Statistics, Government of Odisha, SC,ST Research and Training Institute , Odisha, Bhubaneswar, National Council of Applied Economic Research, New Delhi, National Institute of Public Finance and Policy, New Delhi, I.C.S.S.R, Kolkata and New Delhi and National Library, Kolkata etc, NIRD, Hyderabad, Bangalore University, Bangalore, University Library, Pune, Punjab University Library, IIPS, Mumbai, IGDR, Mumbai., Gujrat Tribal Research and Training Institute Ahmedabad, Mohanlal Sukhadia University Udaipur, M.L.Patel Tribal Research Institute, jaipur.

\section{RESULTS AND DISCUSSION}

Results of the present study obtained from the analysis of field data are presented in this chapter. The total discussion concentrated on the literacy rate, enrolment in education, discontinuance rate, reasons for discontinuance and at last a brief comparison of the situation of the sample tribal households between 1999, 2008 and with the present literacy situation during 2015.

\section{Section -I. Status of Participation in Panchayati Raj of Kolha Households. Number of Households:}

Table-4.1 Presents the distribution of sample scheduled tribe households belonging to three different tribal communities - Kolha, Bhumija and Bathudis . Out of 290 sample households taken under study, 112 households belong to the Kolha community, 85 households belong to the Bhumija community and 93 households belong to Bathudi community. In terms of percentage, the Kolha community comes to 38.62 followed by Bhumijas 29.31 and the Bathudis 32.07 percent.

Table 4.1:Distribution of Sample Tribal households among Three Tribal Communities

\begin{tabular}{|c|c|c|c|}
\hline $\begin{array}{c}\text { Sl } \\
\text { No }\end{array}$ & Category of households & Size of sample & Percentage \\
\hline 1 & Kolha & 112 & 38.62 \\
\hline 2 & Bhumija & 85 & 29.31 \\
\hline 3 & Bathudi & 93 & 32.07 \\
\hline 4 & Pooled & 290 & 100 \\
\hline
\end{tabular}

\section{Literacy status of the Kolha Sample households:}

Literacy status indicates the prospect of human capital formation, growth of income, well being , progress, consciousness about political participation in Panchayati Raj, awareness of health,, as well as creation 
of ideal future generation of the community. On this consideration, in the present study, the data regarding level of education of the sample Kolha households are presented in Table .3

Taking the Kolha sample households into account, the percentage of literate comes to 62.92 and that of illiterate 39.08. It is found that the matter gender wise literacy rate explains the integrated consciousness and foresight of the community. In respect of gender wise literacy rate, the male literacy is much higher, i. e. 73.88 as compared to the females 52.67 percent

Table $-4 . .2$

Literacy status of the Kolha Sample Tribal Households

\begin{tabular}{|c|c|c|c|c|}
\hline \multirow{2}{*}{$\begin{array}{c}\text { Sl } \\
\text { No }\end{array}$} & \multirow[t]{2}{*}{ Category of literacy } & \multicolumn{3}{|c|}{ Population } \\
\hline & & Male & Female & Total \\
\hline 1 & Illiterate & $\begin{array}{c}64 \\
(26.12)\end{array}$ & $\begin{array}{c}124 \\
(47.33)\end{array}$ & $\begin{array}{c}198 \\
(37.08)\end{array}$ \\
\hline 2 & Literate ( Effective literacy) & $\begin{array}{c}181 \\
(73.88)\end{array}$ & $\begin{array}{c}138 \\
(52.67)\end{array}$ & $\begin{array}{c}319 \\
(62.92)\end{array}$ \\
\hline 3 & $\begin{array}{c}\text { Number of literates in Primary } \\
\text { Education }\end{array}$ & $\begin{array}{c}84 \\
(34.29)\end{array}$ & $\begin{array}{c}91 \\
(34.73)\end{array}$ & $\begin{array}{c}175 \\
(34.52)\end{array}$ \\
\hline 4 & $\begin{array}{l}\text { Number of literates in } \\
\text { M.E.Education }\end{array}$ & $\begin{array}{c}26 \\
(10.61)\end{array}$ & $\begin{array}{c}18 \\
(6.87)\end{array}$ & $\begin{array}{c}44 \\
(8.68)\end{array}$ \\
\hline 5 & $\begin{array}{c}\text { Number of literates not } \\
\text { completed secondary education }\end{array}$ & $\begin{array}{c}61 \\
(24.89)\end{array}$ & $\begin{array}{c}20 \\
(7.63)\end{array}$ & $\begin{array}{c}81 \\
(15.98)\end{array}$ \\
\hline 6 & Literates completed secondary & - & $\begin{array}{c}09 \\
(3.44)\end{array}$ & - \\
\hline 7 & $\begin{array}{l}\text { Literates not completed }+2 \\
\text { Education }\end{array}$ & $\begin{array}{c}07 \\
(2.86) \\
\end{array}$ & - & $\begin{array}{c}16 \\
(3.16) \\
\end{array}$ \\
\hline 8 & $\begin{array}{l}\text { Literates completed }+2 \\
\text { Education }\end{array}$ & - & - & - \\
\hline 9 & Literates below Education & $\begin{array}{c}01 \\
(0.41)\end{array}$ & - & $\begin{array}{c}01 \\
(0.19)\end{array}$ \\
\hline 10 & Literate Completed degree & - & - & - \\
\hline 11 & $\begin{array}{l}\text { Literates completed P.G } \\
\text { Education }\end{array}$ & - & - & - \\
\hline 12 & $\begin{array}{c}\text { Literates completed } \\
\text { professional Education }\end{array}$ & $\begin{array}{c}02 \\
(0.82)\end{array}$ & - & $\begin{array}{c}02 \\
(0.39)\end{array}$ \\
\hline 13 & Total & $\begin{array}{c}245 \\
(100)\end{array}$ & $\begin{array}{c}262 \\
(100)\end{array}$ & $\begin{array}{c}507 \\
(100)\end{array}$ \\
\hline
\end{tabular}

Figures in the brackets indicate percentage.

In respect of female illiteracy, it is 47.33 percent as compared to the male illiteracy, i.e. 26.12 percent. Inconsideration of te level of education of the Kolha Sample households, it is revealed that the majority of literates in the Kolha households have primary education ( 34.52 percent) followed by 15.58 percent continues up to below secondary level, 8.68 percent have M.E Education, and very negligible population of sample household, i. e, 3.16 percent have higher secondary education and only 0.39 percent have a professional qualification relating to Diploma Course with Secondary and Intermediate and only 0.19 percent have degree educational qualification.

In respect of male literacy, out of 73.88 percent of male literacy, the higher percentage of male literate have primary education (34.29) followed by 24.89 percent have below secondary education, 10.61 percent having M.E. Education , 2.86 percent below +2 education and only 0.82 percent have professional education and only 0.41 belongs to degree education.

The data reveals that the female literacy is very less in the Kolha sample households, i. e. 52.67 percent. Out of the total female literates , 34.73 percent females have primary education followed by 7.63 percent have education below secondary, 6.87 have M.E Education , 3.44 percent have not completed +3 Education and no female members seen having qualification above secondary in the Kolha sample households.

In short, effective literacy of Kolha sample house holds stands at 62.92 percent out of which male literacy is 73.88 percent and female literacy is 52.67 percent. The maximum literate belongs to primary education. But the surprising fact is that the maximum literates having secondary education are below secondary and success rate is very much negligible. Very negligible portion have education above secondary. The female literacy is very much discouraging. Maximum females have literacy up to primary and negligible continued up to and lowest have continued up to secondary. The level of female education above secondary is out of place to mention here.

Enrollment in education depicts the participation in education or flow or speed of education in the society. The data regarding enrollment in Kolha sample household is presented in Table -4.4

In this analysis, enrollment ratio has been calculated out of the total population aged five years and above and their participation in the education which can present the enrollment of all ages and total population of the sample households which is different from the calculation of others.

DOI: $10.9790 / 0837-2206101423 \quad$ www.iosrjournals.org $\quad 16 \mid$ Page


The enrollment of Kolha sample households clearly reveals that out of total population aged five years and above, only 62.92 percent enrolled in education and 37.08 percent no enrolled at all for schooling. The enrollment ratio is higher in case of male, i. e, 73.88 percent where as the female enrollment ratio is much lower , i. e . 52.67 percent. The male non-enrollment ratio is 26.12 percent where as it is much higher for the female of Kolha community, i. e. 47.33 percent .

The enrollment ratio is higher in primary education ( 34.52 percent) followed by secondary education (15.98 percent), M.E. Education 8.68 percent , 3.16 in higher secondary, 0.39 in professional course and 0.20 percent in degree level. In respect of male, the enrollment ratio is primary is higher (34.29 percent) followed by 24.90 percent in secondary, 10.61 in M.E. , 2.86 percent in higher secondary , 0.82 percent in professional education and 0.41 percent in degree education. In respect of female enrollment ratio , the highest enrollment of female is in primary education (34.73 percent) followed by 7.63 percent in secondary education, 6.87 percent in M.E. education and 3.44 up to higher secondary education. No female is seen having enrollment after higher secondary education.

In short, the enrollment ratio is higher in the case of male, where as it is lower in case of female. The non-enrollment ratio is much higher in female community in comparison to the male population . The higher enrollment is seen in primary education for both male and female and very less in secondary and M.E. education and enrollment is very much negligible after secondary education. No one is found has been enrolled in P.G class of the Kolha community.

\section{Section-II: Literacy status of Bhumija Sample households.}

After having discussed the details of literacy aspect of Kolha sample households, now the discussion will concentrate on the all literacy aspects and dimensions of Bhumija sample households. During the collection of data 85 Bhumija sample households have been collected constituting 29.31 percent of total sample surveyed. The discussion will evolve from the composition of the family, literacy status, continuance and discontinuance of education by the members of sample households and its different directions and the data in this aspect will be presented in form of Table 4.9 to 4.15 .

\section{Composition of the family:}

Composition of the family is one most important indicator for he assessment of literacy status of the community. In this light the data has been obtained from different sample families of Bhumija households are presented in table 4.3

Table-4.3.Demographic profile of Bhumija Sample households

\begin{tabular}{|c|c|c|c|c|}
\hline S1 & Category of population & \multicolumn{3}{|c|}{ Total population } \\
\cline { 2 - 5 } No & & Male & Female & Total \\
\hline 1 & Total Adult population & 116 & 122 & 238 \\
& & $(1.37)$ & $(1.43)$ & $(2.80)$ \\
& & $(31.44)$ & $(33.06)$ & $(64.50)$ \\
\hline 2 & Total Children above five years & 54 & 58 & 112 \\
& & $(0.64)$ & $(0.68)$ & $(1.32)$ \\
& & $(14.63)$ & $(15.72)$ & $(30.35)$ \\
\hline 3 & Total population of adult and children & 170 & 180 & 350 \\
& above five years & $(2.01)$ & $(2.11)$ & $(4.12)$ \\
& & $46.07)$ & $(48.78)$ & $(94.85)$ \\
\hline 4 & Total children below five years & 10 & 9 & 19 \\
& & $(0.11)$ & $(0.11)$ & $(0.22)$ \\
& & $(2.71)$ & $(2.44)$ & $(5.15)$ \\
\hline 5 & Total population & 180 & 189 & 369 \\
& & $(2.12)$ & $(2.22)$ & $(14.34)$ \\
& & $(48.78)$ & $(51.22)$ & $(100)$ \\
\hline
\end{tabular}

- $\quad$ figures in the first bracket indicates averages.

- * figures in the second bracket indicates percentages.

Observation reveals that the total population of Bhumija sample households is 369 within which total male population 180 and female population constitute 189 The total adult female is 122 out numbers the adult males 116. Similarly in respect of total children above five years, female members is 58 which is more than the male members -54- and total children above 5 years works out to 112. So the total population of adult members and the children above five years, the total comes to 350 Out of -350 total members 180 is total female members is greater than the male members, i. e. 170. But the data reveals that the total children below five years is 19 , out of which the male Children (10 is more as compared to the female children (9).

In terms of average, the average family size of the Bhumija community works out to 4.34 as compared to the female (2.22) and males (2.12). The average adult member is 2.80 followed by children above five years 
1.32 and children less than five years is 0.22 In respect of males, the average male member is 2.12 , out of which 1.37 belongs to adult male followed by 0.64 , male children above five years and 0.11 male children less than five years. Similarly, in respect of average size of female members of the Bhumija community, it is worked out to 2.22 , followed by adult female 1.43 , female children above five years 0.68 and female children less than five years is 0.11

\section{Literacy status of the Bhumija Sample households:}

Literacy status indicates the prospect of human capital formation, growth of income, well being , progress, consciousness about health, as well as creation of ideal future generation of the community. On this consideration, in the present study, the data regarding level of education of the sample Bhumija households are presented in Table-4.10

Taking Bhumija sample households into account, the percentage of literate comes to 52.0 and that of illiterate 48.0. In respect of gender wise literacy rate , the male literacy is much higher, i. e. 62.35as compared to the females 42.22

Table -4.4

Literacy status of the Bhumija Sample Tribal Households

\begin{tabular}{|c|c|c|c|c|}
\hline \multirow{2}{*}{$\begin{array}{c}\text { S1 } \\
\text { No }\end{array}$} & Category of literacy & \multicolumn{3}{c|}{ Population } \\
\cline { 2 - 5 } & & Male & Female & Total \\
\hline 1 & Illiterate & 64 & 104 & 168 \\
& & $(37.65)$ & $(57.78)$ & $(48.0)$ \\
\hline 2 & Literate ( Effective literacy) & 106 & 76 & 182 \\
& & $62.35)$ & $(42.22)$ & $(52.0)$ \\
\hline 3 & Number of literates in Primary Education & 45 & 43 & 88 \\
& & $(26.47)$ & $(23.88)$ & $(25.14)$ \\
\hline 4 & Number of literates in M.E.Education & 16 & 10 & 26 \\
& & $(9.41)$ & $(5.56)$ & $(7.43)$ \\
\hline 5 & Number of literates not completed secondary & 31 & 19 & 50 \\
& education & $(18.24)$ & $(10.56)$ & $(14.28)$ \\
\hline 6 & Literates completed secondary & - & - & - \\
\hline 7 & Literates not completed +2 Education & 6 & 3 & 9 \\
& & $(3.53)$ & $(1.66)$ & $(2.57)$ \\
\hline 8 & Literates completed +2 Education & 2 & 1 & 3 \\
& & $(1.18)$ & $(0.56)$ & $(0.86)$ \\
\hline 9 & Literates below Education & 3 & - & 3 \\
& & $(1.76)$ & & $(0.86)$ \\
\hline 10 & Literate Completed degree & 3 & - & 3 \\
& & $(1.76)$ & & $(0.86)$ \\
\hline 11 & Literates completed P.G Education & - & - & - \\
\hline 12 & Literates completed professional Education & - & - & - \\
\hline 13 & Total & 170 & 180 & $(100)$ \\
\hline
\end{tabular}

Figures in the brackets indicate percentage.

In respect of female illiteracy, it is 57.78 percent as compared to the male illiteracy, i.e. 37.64 percent. Inconsideration of the level of education of the Bhumija Sample households, it is revealed that the majority of literates in the Bhumija households have primary education ( 25.14 percent) followed by 14.28 percent continues up to below secondary level, 7.43 percent have M.E Education, and very negligible population of sample household, i. e, 2.57 percent have not completed higher secondary education and only 0.86 completed higher secondary education , 0.86 percent each have not completed degree education and 0.86 percent completed degree education.

In respect of male literacy, out of 62.35 percent of male literacy, the higher percentage of male literate have primary education (26.47) followed by 18.24 percent have below secondary education, 9.41 percent having M.E. education , 3.53percent below +2 education and only 1.18 percent have completed +3 education and only 1.76 percent have not completed degree education and another 1.76 percent completed degree education.

The data reveals that the female literacy is very less in the Bhumija sample households, i. e. 42.22 percent. Out of the total female literates , 23.88 percent females have primary education followed by 10.56 percent have education below secondary, 5.56 have M.E Education 1.66 percent have not completed +2 Education and 0.56 percent female members seen having qualification of higher secondary education in the Bhumija sample households.

In short, the literacy status reflects that the male literacy is much higher than female literacy in the Bhumija sample households,. So, the illiteracy rate is much higher among the females of sample households than the male. Out of total literates maximum percentage of sample tribal households have primary education 
followed by the proportion not completed secondary education. So also, the literates having M.E. education is better than literates not completed +2 education. The literates having degree education and the literates not completed degree education are very much negligible. In respect of literates having PG and professional degree does not arise both in the case of males and females of Bhumija sample households.

\section{Section-III: Literacy status of Bathudi Sample households.}

In the present section, the detail information regarding demographic profile, literacy status, enrollment ratio, reasons for discontinuance in different levels of education, discontinuance and continuance of the Bathudi sample households will be discussed in this section.

\section{Composition of the family:}

Composition of the family is one most important indicator for the assessment of literacy status of the community. In this light the data has been obtained from different sample families of Bathudi households are presented in table 4.5

Table -4.5

.Demographic profile of Bathudi Sample households

\begin{tabular}{|c|c|c|c|c|}
\hline \multirow{2}{*}{$\begin{array}{r}\text { S1 } \\
\text { No }\end{array}$} & \multirow[t]{2}{*}{ Category of population } & \multicolumn{3}{|c|}{ Total population } \\
\hline & & Male & Female & Total \\
\hline 1 & Total Adult population & $\begin{array}{c}150 \\
(1.61) \\
(34.40)\end{array}$ & $\begin{array}{c}139 \\
(1.49) \\
(31.88)\end{array}$ & $\begin{array}{c}289 \\
(3.10) \\
(66.28)\end{array}$ \\
\hline 2 & Total Children above five years & $\begin{array}{c}63 \\
(0.68) \\
(14.45)\end{array}$ & $\begin{array}{c}53 \\
(0.57) \\
(12.16)\end{array}$ & $\begin{array}{c}116 \\
(1.25) \\
(26.61)\end{array}$ \\
\hline 3 & $\begin{array}{l}\text { Total population of adult and children above } \\
\text { five years }\end{array}$ & $\begin{array}{c}213 \\
(2.29) \\
(48.85)\end{array}$ & $\begin{array}{c}192 \\
(2.06) \\
(44.04)\end{array}$ & $\begin{array}{c}405 \\
(4.35) \\
(92.89)\end{array}$ \\
\hline 4 & Total children below five years & $\begin{array}{c}19 \\
(0.20) \\
(4.36)\end{array}$ & $\begin{array}{c}12 \\
(0.13) \\
(2.75)\end{array}$ & $\begin{array}{c}31 \\
(0.33) \\
(7.11)\end{array}$ \\
\hline 5 & Total population & $\begin{array}{c}232 \\
(2.49) \\
(53.21)\end{array}$ & $\begin{array}{c}204 \\
(2.19) \\
(46.79)\end{array}$ & $\begin{array}{c}436 \\
(4.68) \\
(100)\end{array}$ \\
\hline
\end{tabular}

- $\quad$ figures in the first bracket indicates averages.

- $\quad$ figures in the second bracket indicates percentages

Observation reveals that the total population of Bathudi sample households is 436 within which total male population 232 and female population constitute 204. The total adult male is 150 out numbers the adult females 139. Similarly in respect of total children above five years, male members is 63 which is more than the female members 53 and total children above 5 years works out to 116. So the total population of adult members and the children above five years, the total comes to 405 Out of 405 total members 213 is total male members is greater than the female members, i. e. 192. But the data reveals that the total children below five years is 31 out of which the male children population 19 is more as compared to the female children 12 .

In terms of average, the average family size of the Bathudi community works out to 4.68 as compared to the male (2.49) and females (2.19). The average adult member is 3.10 followed by children above five years 1.25 and children less than five years is 0.33 In respect of males, the average male member is 2.49 , out of which 1.61 belongs to adult male followed by 0.68 male children above five years and 0.20 male children less than five years. Similarly, in respect of average size of female members of the Bathudi community, it is worked out to 2.19 , followed by adult female 1.49 , female children above five years 0.57 and female children less than five years is 0.13

\section{Literacy status of the Bathudi Sample households:}

Literacy status indicates the prospect of human capital formation, growth of income, well being, progress, consciousness about health, as well as creation of ideal future generation of the community. On this consideration, in the present study, the data regarding level of education of the sample Bathudi households are presented in

\section{Table-4.6}

Taking Bathudi sample households into account, the percentage of literate comes to 73.58 percent and that of illiterate 26.42. In respect of gender wise literacy rate, the male literacy is higher, i. e. 77.93 as compared to the females 68.75 percent

Table 4.6

Literacy status of the Bathudi Sample Tribal Households 


\begin{tabular}{|c|c|c|c|c|}
\hline \multirow{2}{*}{$\begin{array}{c}\text { S1 } \\
\text { No }\end{array}$} & \multirow[t]{2}{*}{ Category of literacy } & \multicolumn{3}{|c|}{ Population } \\
\hline & & Male & Female & Total \\
\hline 1 & Illiterate & $\begin{array}{c}47 \\
(22.07)\end{array}$ & $\begin{array}{c}60 \\
(31.25)\end{array}$ & $\begin{array}{c}107 \\
(26.42)\end{array}$ \\
\hline 2 & Literate ( Effective literacy) & $\begin{array}{c}166 \\
(77.93) \\
\end{array}$ & $\begin{array}{c}132 \\
(68.75) \\
\end{array}$ & $\begin{array}{c}298 \\
(73.58) \\
\end{array}$ \\
\hline 3 & $\begin{array}{c}\text { Number of literates in Primary } \\
\text { Education }\end{array}$ & $\begin{array}{c}90 \\
(42.25)\end{array}$ & $\begin{array}{c}66 \\
(34.38)\end{array}$ & $\begin{array}{c}156 \\
(38.52)\end{array}$ \\
\hline 4 & Number of literates in M.E.Education & $\begin{array}{c}15 \\
(7.04)\end{array}$ & $\begin{array}{c}11 \\
(5.72)\end{array}$ & $\begin{array}{c}26 \\
(6.42) \\
\end{array}$ \\
\hline 5 & $\begin{array}{l}\text { Number of literates not completed } \\
\text { secondary education }\end{array}$ & $\begin{array}{c}46 \\
(21.60)\end{array}$ & $\begin{array}{c}44 \\
(22.92) \\
\end{array}$ & $\begin{array}{c}90 \\
(22.22)\end{array}$ \\
\hline 6 & Literates completed secondary & - & - & - \\
\hline 7 & Literates not completed +2 Education & $\begin{array}{c}10 \\
(4.69)\end{array}$ & $\begin{array}{c}6 \\
(3.13) \\
\end{array}$ & $\begin{array}{c}16 \\
(3.95) \\
\end{array}$ \\
\hline 8 & Literates completed +2 Education & - & - & - \\
\hline 9 & Literates below degree Education & $\begin{array}{c}5 \\
(2.35) \\
\end{array}$ & $\begin{array}{c}5 \\
(2.60) \\
\end{array}$ & $\begin{array}{c}10 \\
(2.47) \\
\end{array}$ \\
\hline 10 & Literate Completed degree & - & - & - \\
\hline 11 & Literates completed P.G Education & - & - & - \\
\hline 12 & $\begin{array}{l}\text { Literates completed professional } \\
\text { Education }\end{array}$ & - & - & - \\
\hline 13 & Total & $\begin{array}{c}213 \\
(100)\end{array}$ & $\begin{array}{c}192 \\
(100)\end{array}$ & $\begin{array}{c}405 \\
(100)\end{array}$ \\
\hline
\end{tabular}

Figures in the brackets indicate percentage.

In respect of female illiteracy, it is 31.25 percent as compared to the male illiteracy, i.e. 22.07 percent. Inconsideration of the level of education of the Bathudi Sample households, it is revealed that the majority of literates in the Bathudi households have primary education (38.52 percent) followed by 22.22 percent continues up to below secondary level, 6.42 percent have M.E Education, and very negligible population of sample household, i. e, 3.95 percent have not completed higher secondary education and only 2.47 have not completed degree education.

In respect of male literacy, out of 77.93 percent of male literacy, the higher percentage of male literate have primary education (42.25) percent followed by 21.60 percent have not completed secondary education. , 7.04 percent having M.E. Education , 4.69 percent below +2 education and only 2.35 percent have not completed +3 education. The data reveals that the female literacy in the Bathudi sample households, i. e. 68.75 percent. Out of the total female literates, 34.38 percent females have primary education followed by 22.92 percent have not completed secondary education, 5.72 have M.E Education 3.13 percent have not completed +2 Education and 2.60 percent female members are seen having not completed degree education.

In short, effective literacy of Bathudi sample households stands at 73.58 percent, out of which male literacy is 77.93 percent and female literacy is 68.75 percent. The maximum literates belongs to primary education. But the surprising fact is that, the maximum literates having secondary education have not completed secondary education and the success rate is very much negligible. Very negligible portion have education above secondary. Maximum females have literacy up to primary and lower amount have continued up to secondary. The level of female education above secondary is very much negligible.

\section{Comparative analysis of educational status of sample households during 2015:}

The comparative analysis of educational status of all sample households of Kolha, Bathudi and Bhumija have been presented in Table 4.7

Table 4.7

Level of Education among the Sample Tribal households aged five years and above during 2015 ( In percentage)

\begin{tabular}{|c|c|c|c|c|c|c|c|c|c|c|c|c|c|}
\hline \multirow{2}{*}{$\begin{array}{c}\mathrm{S} \\
1 \\
\mathrm{~N} \\
\mathrm{o}\end{array}$} & \multirow{2}{*}{$\begin{array}{l}\text { Catego } \\
\text { ry of } \\
\text { literacy }\end{array}$} & \multicolumn{3}{|c|}{ Kolha } & \multicolumn{3}{|c|}{ Bathudi } & \multicolumn{3}{|c|}{ Bhumija } & \multicolumn{3}{|c|}{ Pooled } \\
\hline & & $\begin{array}{c}\mathrm{Ma} \\
\text { le }\end{array}$ & $\begin{array}{c}\text { Fem } \\
\text { ale }\end{array}$ & $\begin{array}{l}\text { Tot } \\
\text { al }\end{array}$ & $\begin{array}{c}\mathrm{Ma} \\
\text { le }\end{array}$ & $\begin{array}{c}\text { Fem } \\
\text { ale }\end{array}$ & $\begin{array}{c}\text { Tot } \\
\text { al }\end{array}$ & $\begin{array}{c}\mathrm{Ma} \\
\text { le }\end{array}$ & $\begin{array}{c}\text { Fem } \\
\text { ale }\end{array}$ & $\begin{array}{l}\text { Tot } \\
\text { al }\end{array}$ & Male & $\begin{array}{c}\mathrm{Fe} \\
\mathrm{mal} \\
\mathrm{e}\end{array}$ & $\begin{array}{c}\text { Tot } \\
\text { al }\end{array}$ \\
\hline 1 & $\begin{array}{c}\text { Illiterat } \\
\mathrm{e}\end{array}$ & $\begin{array}{l}26 . \\
12\end{array}$ & $\begin{array}{c}47.3 \\
3\end{array}$ & $\begin{array}{l}39 . \\
08\end{array}$ & $\begin{array}{l}22 . \\
97\end{array}$ & $\begin{array}{c}31.2 \\
5\end{array}$ & $\begin{array}{l}26 . \\
42\end{array}$ & $\begin{array}{l}37 . \\
65\end{array}$ & $\begin{array}{c}57.7 \\
8\end{array}$ & $\begin{array}{c}48 . \\
0\end{array}$ & 27.87 & $\begin{array}{l}45 . \\
43\end{array}$ & $\begin{array}{l}36 . \\
69\end{array}$ \\
\hline & $\begin{array}{c}\text { Liter } \\
\mathrm{e}\end{array}$ & $\begin{array}{l}73 . \\
88\end{array}$ & $\begin{array}{c}52.6 \\
7\end{array}$ & $\begin{array}{l}62 . \\
92\end{array}$ & $\begin{array}{l}77 . \\
93\end{array}$ & $\begin{array}{c}68.7 \\
5\end{array}$ & $\begin{array}{c}73 . \\
58\end{array}$ & $\begin{array}{l}62 . \\
35\end{array}$ & $\begin{array}{c}42.2 \\
2\end{array}$ & $\begin{array}{c}52 . \\
0\end{array}$ & 72.13 & $\begin{array}{l}54 . \\
57\end{array}$ & 3 \\
\hline
\end{tabular}




\begin{tabular}{|c|c|c|c|c|c|c|c|c|c|c|c|c|c|}
\hline & & & & & & & & & & & & & \\
\hline 3 & $\begin{array}{c}\text { Literat } \\
\mathrm{e} \\
\text { having } \\
\text { Primar } \\
\mathrm{y} \\
\text { Educati } \\
\text { on }\end{array}$ & $\begin{array}{l}34 . \\
29\end{array}$ & $\begin{array}{c}34.7 \\
3\end{array}$ & $\begin{array}{l}34 . \\
52\end{array}$ & $\begin{array}{l}42 . \\
25\end{array}$ & $\begin{array}{c}34.3 \\
8\end{array}$ & $\begin{array}{l}38 . \\
52\end{array}$ & $\begin{array}{l}26 . \\
47\end{array}$ & $\begin{array}{c}23.8 \\
8\end{array}$ & $\begin{array}{r}25 . \\
14\end{array}$ & 34.87 & $\begin{array}{l}31 . \\
55\end{array}$ & $\begin{array}{l}33 . \\
20\end{array}$ \\
\hline 4 & $\begin{array}{c}\text { Literat } \\
\mathrm{e} \\
\text { having } \\
\text { M.E } \\
\text { Educati } \\
\text { on }\end{array}$ & $\begin{array}{c}10 . \\
61\end{array}$ & 6.87 & $\begin{array}{c}8.6 \\
8\end{array}$ & $\begin{array}{c}7.0 \\
4\end{array}$ & 5.72 & $\begin{array}{c}6.4 \\
2\end{array}$ & $\begin{array}{c}9.4 \\
1\end{array}$ & 5.56 & $\begin{array}{c}7.4 \\
3\end{array}$ & 9.08 & $\begin{array}{c}6.1 \\
5\end{array}$ & $\begin{array}{c}7.6 \\
1\end{array}$ \\
\hline 5 & $\begin{array}{c}\text { Literat } \\
\text { e } \\
\text { having } \\
\text { second } \\
\text { ary } \\
\text { educati } \\
\text { on }\end{array}$ & $\begin{array}{l}24 . \\
89\end{array}$ & 7.63 & $\begin{array}{l}15 . \\
98\end{array}$ & $\begin{array}{c}21 . \\
60\end{array}$ & $\begin{array}{c}22.9 \\
2\end{array}$ & $\begin{array}{l}22 . \\
22\end{array}$ & $\begin{array}{l}18 . \\
24\end{array}$ & $\begin{array}{c}10.5 \\
6\end{array}$ & $\begin{array}{l}14 . \\
28\end{array}$ & 21.97 & $\begin{array}{l}13 . \\
09\end{array}$ & $\begin{array}{l}17 . \\
51\end{array}$ \\
\hline 6 & $\begin{array}{l}\text { Literat } \\
\text { es } \\
\text { having } \\
\text { educati } \\
\text { on } \\
\text { above } \\
\text { second } \\
\text { ary }\end{array}$ & $\begin{array}{c}4.0 \\
9\end{array}$ & 3.44 & $\begin{array}{c}3.7 \\
4\end{array}$ & $\begin{array}{c}7.0 \\
4\end{array}$ & 5.73 & $\begin{array}{c}6.4 \\
2\end{array}$ & $\begin{array}{c}8.2 \\
3\end{array}$ & 2.22 & $\begin{array}{c}5.1 \\
5\end{array}$ & 6.21 & $\begin{array}{c}3.7 \\
8\end{array}$ & $\begin{array}{c}4.9 \\
9\end{array}$ \\
\hline 7 & Total & 100 & 100 & 100 & 100 & 100 & 100 & 100 & 100 & 100 & 100 & 100 & 100 \\
\hline
\end{tabular}

The data reveals that, in respect of illiteracy, the Bathudi households have lowest illiteracy rate, i. e, 26.42 percent followed by 39.08 percent in Kolha and the highest illiteracy ( 48.0 percent)is found in case of Bhumijas. The pooled data of all sample households shows that the illiteracy stands at 36.69 percent .

In respect of literacy in the sample households, the highest literacy rate is found among Bathudis, i.e. 73.58 percent , followed by Kolha 62.92 percent and the Bhumijas 52.0 percent. The pooled data of all sample households shows that the literacy is 63.31 percent. The male literacy is highest is in Bathudis ( 77.93 percent) followed by Kolha (73.58 percent) and the Bhumijas (62.35 percent) and the pooled data stands at 72.13 percent . Similarly, the female illiteracy is highest in Bhumija households ( 57.78 percent), followed by Kolhas (47.33 percent) and the Bathudis (31.25 percent). The female literacy is highest in Bathudi sample households, i. e. 68.75 percent followed by Kolhas (52.67 percent) and for the Bhumijas, it is 42.42 percent and the pooled data stands at 54.57 percent.

The data reveals that the highest rate of literates in sample tribal households belong to primary education and among the households, the Bathudis have highest primary literates (38.52 percent), followed by Kolha (34.52 percent) and the Bhumijas (25.14 percent) . The pooled data in this respect is 33.20 percent. In respect of males, the highest literates having primary education belongs to Bathudi males, i.e. 42.25 percent followed by 34.29 percent of Kolhas and 26.47 percent of the Bhumijas and the pooled data is 34.87 percent. In respect of females, having primary education, the highest belongs to Kolha community, i.e. 34.73 percent followed by Bathudis 34.38 percent and 23.88 percent in the case of Bhumijas and the pooled data is 31.55 percent.

The comparative analysis in respect of ME education among the sample households shows that the Kolhas have higher ME education ( 8.68 percent) followed by Bhumijas ( 7.43 percent) and the Bathudis (6.42 percent) and the pooled data is 7.61 percent. In respect of males, the Kolhas have male with higher ME education, i.e. 10.61 percent followed by 9.41 percent belongs to Bhumijas and 7.04 percent of Bathudis and the pooled data in this respect is 9.08 percent. In respect of females the corresponding rate stands at 6.87 percent for Kolhas , 5.72 percent for Bathudis and 5.56 percent for the Bhumijas. The pooled data for females is 6.15 percent. 
The data shows that the Bathudis have higher literates (22.22 percent) belong to secondary education followed by Kolhas (15.98 percent), Bhumijas (14.28 percent) and the pooled data is 17.51 percent. In respect of males having secondary education, higher proportion belongs to Kolhas ( 24.89 percent) followed by Bathudis (21.60 percent) and the Bhumijas (18.24 percent) and the pooled data stands at 21.97 percent. In respect of females belonging to same education group , Bathudi females have maximum literacy of secondary, i.e 22.92 percent followed by the Bhumijas (10.56 percent) and the lowest being the Kolhas ( 7.63 percent). The pooled data in this respect is 13.09 percent.

The information regarding the literacy position of sample households in respect of literates having education above secondary level, it is revealed that the Bathudis have higher proportion (6.42 percent) having literacy above secondary level, followed by the Bhumijas ( 5.15 percent) and the Kolhas ( 3.74 percent) and the pooled data is 4.99 percent. The corresponding figures for male is 8.23 percent for Bhumijas , 7.04 percent for Bathudis , 4.09 percent for Kolhas and the pooled data is 6.21 percent. In respect of females having literacy above secondary level, it is observed that, the highest Bathudi females, i.e. 5.73 percent have literacy above secondary level followed by 3.44 percent of Kolhas , 2.22 percent of Bhumijas and the pooled data stands at 3.78 percent. In short, the Bathudi households have higher literacy rate than Kolhas and Bhumijas .In respect of illiteracy, the Bhumijas have highest illiteracy rate as compared with the Kolhas and Bathudis. In all sample households male literacy is higher than female literacy rate. Maximum literates belong to primary education followed by secondary education. The proportion of literates are very low in ME education and above secondary education.

\section{SUMMARY CONCLUSION AND POLICY IMPLICATIONS.}

The study has examined the nature and dimension s of literacy, discontinuance in education and the comparative study of the present analysis of 2015 with the data collected during 1999 and 2008 from the same sample village and from Kolha, Bathudi and Bhumija sample households of Nilgiri ITDA Block in Balasore district of Odisha .

An analysis of the literary status of the sample tribal households in the study area reveals that the literacy percentage of all sample tribal households taken together stands at 63.31 percent which is at par with the state average for tribals 63.08 percent but it is lower than the district average for general population 79.79 percent and 72.87 percent of state average and lower than national average for tribals (64.8 percent) and average literates of India (74.04 percent) as per 2011 census. As such the hypothesis -1 states that the sample households leg behind in literacy rate of the state and country is found proved from the findings of the study.

Similarly, in regard to male literacy the data reveals that 72.13 percent of sample population are literate which is lower than state average (75.35 percent) and national average (75.3 percent) for tribals. The tribal's literacy rate of sample households is lower than the district average literacy rate (87.0) percent, state average literacy rate 81.59 percent and National average 82.14 percent as per 2011 census.

In respect of female literacy of sample households, the pooled data of all sample households worked out to 54.57 percent which is above the average female literacy (50.51 percent) for the tribals of the state and National female average literacy for tribals 53.7 percent) The literacy of female tribal households is lower than the average female literacy of the district $(72.28$ percent), state average for females (64.01 percent) and National average literacy for females (65.46 percent) as per 2011 census.

The analysis regarding the sample households of Kolha, Bathudi and Bhumija , reflects that the literacy rate is highest in Bathudi community (73.58 percent) followed by Kolha (62.92 percent) and the lowest literacy rate is found in Bhumija community (52.0) percent. The hypothesis that the literacy rate among the Bathudis are higher as compared to the Kolhas and Bhumijas in the sample households is found proved from the findings of the study. In respect of male literacy in the sample households 77.93 percent of Bathudi males are literate as compared to the Kolha 73.88 percent and

62.35 percent of male of Bhumija community are literate. Regarding the female literacy among the tribal households, it is evident that the female literacy is higher among the Bathudi females (68.75 percent) followed by Kolha females (62.92 percent) and the lowest is found among the Bhumija females (42.22 percent) .But the literacy rate of male in the sample households (72.13 percent) is higher than female literacy rate of the sample households(54.57 percent)and this is irrespective of the communities. The hypothesis as such, the literacy rate among the male is higher than the females in the sample tribal houses is found proved from the findings of the strudy.

With regards to illiteracy among the same tribal households, taking all the three communities together, it is found that 36,69 percent are illiterate out of which the higher percentage of females are illiterate (45.43 percent) as compared to the males (27.87 percent). Among the sample households, the highest illiteracy is found among the Bhumijas (48.0percent) in comparison with Kolhas (39.08 percent) and the Bathudis (26.42 percent). In the matter of illiteracy of males, 37.65 illiterate males belong to Bhumija community followed by Kolha (26.12 percent) and the Bathudis (22.97 percent). The female illiteracy among the sample households 
reflect that the highest female illiteracy is seen among the Bhumija females (57.78 percent) as compared to the females of Kolha community (47.33 percent) and the Bathudi Community (31.25 percent)

\section{CONCLUSSION:}

The measure findings of the study are :

1. All the three sample tribal households - Kolha, Bathudi and Bhumijas taken together shows that the average literacy rate is at par with the state average for tribals but lower than the national average for tribals. The literacy of sample tribal households lower than the average literacy rate of all population of district, state and national average as per 2011 census.

2. Similarly, in respect of male literacy, the data reveals that the average male literacy of sample population are lower than the state average and the national average for tribals. The tribal male literacy rate of sample households is lower than the district average literacy, state average literacy rate and national average for all people as per 2011 census.

3. In respect of female literacy, the female members of the households, the average female literacy is higher than the average female literacy of the state and nation but the average female literacy of the tribal sample households is lower than the average female literacy of the district, state and for nation as per 2011 census.

4. The Kolha, Bathudi and Bhumija sample households reflect that the literacy rate is highest in Bathudi households followed by Kolha and the lowest is in Bhumija households.

5. In respect of male literacy in sample households, the Bathudi males are more literates as compared to the male of Kolha and the male of Bhumija.

6. Regarding the female literacy among the tribal sample households, it is evident that the female literacy is higher among the Bathudi females in comparison to Kolha females and the lowest is found among the Bhumija females.

7. The analysis of literacy in different levels of education, the maximum literates belong to primary education followed by secondary education. But the concentration of literates in ME education and the literates having education above secondary are of minor importance.

8. In the matter of discontinuance in primary level and secondary level, the reasons are many out of which the poverty is the main reason which pushes the male child to be engaged as child labour, collection of minor forest produce, to take care of animals and goats on the wage basis, whereas the female children are engaged as child labour and in collection of minor forest produce, to take care of children at home when parents go for work and to help parents in domestic work. The reasons for discontinuance in secondary education are mostly due to failure in HSC examination and the other cause is the early marriage for females. The discontinuance in higher secondary class and degree class is mostly due to failure in higher secondary and university examination, the other causes are engagement in government and private sector employment and early marriage. The discontinuance in ME education is similar with the reasons for discontinuance for primary education.

9. The comparative analysis of different periods in the sample households of Kolha, Bathudi and Bhumijas during 1999, 2008 and 2015, shows that there is remarkable growth of literacy rate among the sample tribal households during the period 2008 to 2015 and there is slow growth of literacy during the period 1999 to 2008. Likewise, the similar trend is seen in the reduction of illiteracy in the sample households during the above said period.

10. Among the sample households, the growth of literacy is highest in Bathudi sample households followed by Kolha households but the growth is lowest in Bhumija sample households. In respect of growth of literacy in different level of education, the growth of literacy in secondary level are of higher order where as the growth of literacy in ME and above secondary are of lower importance.

In traditional society control \& access of any decision making lie in the hands of the elder people. By the study of age (figure 9) we would try to find out whether in this variant society baton of the relay race of Panchayat leadership has been handed over to the younger group by the elder group or not. This illustrates that the educational level of WERs in age group (25-35) is lower. EWR from both blocks have low level of education majority of them were only primary educated and only 2 percent member is graduated in both blocks, it clearly indicates that the participation of respondents with below secondary education tends to be more in local governance. The age group 45-55 has more percent in primary education. Age group, 36-45 yr, is average percent in all level education. It is an accepted fact that the overall educational status of female is quite low in all the GP. 